\title{
Euroskepticism, a multifaceted phenomenon
}

Citation for published version (APA):

Bijsmans, P. (2020). Euroskepticism, a multifaceted phenomenon. In Oxford Research Encyclopedia of Politics Oxford University Press. https://doi.org/10.1093/acrefore/9780190228637.013.1062

Document status and date:

Published: 01/02/2020

DOI:

10.1093/acrefore/9780190228637.013.1062

Document Version:

Publisher's PDF, also known as Version of record

Document license:

Taverne

Please check the document version of this publication:

- A submitted manuscript is the version of the article upon submission and before peer-review. There can be important differences between the submitted version and the official published version of record.

People interested in the research are advised to contact the author for the final version of the publication, or visit the DOI to the publisher's website.

- The final author version and the galley proof are versions of the publication after peer review.

- The final published version features the final layout of the paper including the volume, issue and page numbers.

Link to publication

\footnotetext{
General rights rights.

- You may freely distribute the URL identifying the publication in the public portal. please follow below link for the End User Agreement:

www.umlib.nl/taverne-license

Take down policy

If you believe that this document breaches copyright please contact us at:

repository@maastrichtuniversity.nl

providing details and we will investigate your claim.
}

Copyright and moral rights for the publications made accessible in the public portal are retained by the authors and/or other copyright owners and it is a condition of accessing publications that users recognise and abide by the legal requirements associated with these

- Users may download and print one copy of any publication from the public portal for the purpose of private study or research.

- You may not further distribute the material or use it for any profit-making activity or commercial gain

If the publication is distributed under the terms of Article $25 \mathrm{fa}$ of the Dutch Copyright Act, indicated by the "Taverne" license above, 


\title{
Euroskepticism, a Multifaceted Phenomenon
}

Patrick Bijsmans, Department of Political Science, Maastricht University

https://doi.org/10.1093/acrefore/9780190228637.013.1062

Published online: 28 February 2020

\begin{abstract}
Summary
In an age of Brexit, Euroskepticism has become a central element in debates about Europe. It is generally believed that there has been an increase in criticism on and opposition toward the European Union (EU) and its policies since the 1991 Maastricht Treaty. Yet, criticism was already present at the start of the integration process, also among mainstream parties in the six founding members. With the EU's recent crises, Euroskepticism has become embedded in contestation in most member states, affecting politics at the national and European level. Consequently, it is important to understand Euroskepticism in contemporary Europe and to gather a broad overview of its development, its meaning, and its wider consequences.
\end{abstract}

Euroskepticism is a diverse, multifaceted phenomenon that varies across time, member states, and policies. Exploring the history of Euroskepticism helps to contextualize contemporary developments and to understand some of the main debates and issues in the field, including conceptual challenges, but also debates about the reasons for Euroskepticism and what kind of impact it might have. One of the key questions in this respect is whether Euroskepticism should be seen as a problematic phenomenon or as an essential element of a democratic Europe. While conventional negative connotations associated with Euroskepticism suggest the former, research finds a broader variety of criticism and opposition to the EU and its policies that may be conducive to a more democratic EU debate.

Keywords: democracy, European Union, European Union politics, Euroskepticism, opposition, politicization

\section{Introduction}

The outcome of the Brexit referendum of June 23, 2016, sent shockwaves through the European Union (EU). While the leave camp beat the remain camp by only a narrow margin of $51.89 \%$ to $48.11 \%$, Britain is unequivocally on its way out of the EU (or so it seems). From the day that Britain joined the then European Communities on January 1, 1973, it quickly became what George (1998) famously called an "awkward partner." Its "outsider tradition" (Daddow, 2015) has been consciously and unconsciously utilized by British prime ministers from Margaret Thatcher to David Cameron and can now also be identified in the ongoing debate about Brexit (Hix, 2018). 
While a shock, given the history of British engagement with the EU, the British voters' decision can hardly be seen as a surprise. Nevertheless, it does raise questions about the future of the integration project in an age in which Euroskepticism has become a "mainstream" phenomenon (Brack \& Startin, 2015), "embedded" in European societies (Usherwood \& Startin, 2013). After the Brexit vote, media were quick to raise the prospect of a "populist spring" that could endanger European integration due to a growing selfconfidence among populist parties across Europe and elections in member states such as France, Germany, and the Netherlands in 2017 (Halikiopoulou, 2018). The populist spring never really happened. While populist parties did gain some votes, opinion poll data published by Pew Research Center (2017) in the same year actually indicated a sharp increase of support for the EU since the Brexit vote (cf. de Vries, 2017, 2018). Eurobarometer data published one year before the 2019 European elections finds that support for the EU was at its highest point since the 1980s, with $60 \%$ of Europeans stating that their country's membership in the EU is a good thing and $67 \%$ believing that their country has benefitted from EU membership (European Parliament, 2018).

Even so, it is clear that we are witnessing a much more critical engagement with the EU, and a better understanding of what Euroskepticism entails is therefore important. Despite the fact that it is generally believed that Euroskepticism has been on the rise since the 1991 Treaty on European Union (the Maastricht Treaty), its advance has been far from uniform across the EU (e.g., Lubbers \& Scheepers, 2010; Taggart \& Szczerbiak, 2018). Yet, in an age of Brexit, Euroskeptic parties have even made their mark in traditionally more pro-European member states (e.g., the German Alternative für Deutschland). Research has particularly focused on party politics and public opinion (e.g., Hobolt \& de Vries, 2016; Rohrschneider \& Whitefield, 2016; Szczerbiak \& Taggart, 2008). Yet, recent years have seen an increasing interest in how Euroskepticism is manifested in other parts of society, such as media (e.g., Caiani \& Guerra, 2017) and transnational politics (e.g., FitzGibbon, Leruth, \& Startin, 2017b).

In this contribution I present an overview of what Euroskepticism entails and how it has become manifested in the EU while highlighting its multifaceted nature and the subsequent need for a broad research agenda. I start with a brief history of Euroskepticism, which shows that opposition to European integration has been present since the early years of integration but has become part and parcel of European politics since the more recent EU crises. Next, I review the debate about the concept of "Euroskepticism," with a particular focus on the difficulty of how to define what essentially is a very diverse phenomenon. Subsequently, I look at empirical research in the field, starting with traditional studies of party politics and public opinion but then expanding the scope to new approaches to Euroskepticism. The penultimate section zooms out again and discusses Euroskepticism and its implications for the EU through the lens of democracy.

\section{A Brief History of Criticism and Opposition to European Integration}

Starting with a historical perspective on Euroskepticism contributes to a broader understanding of Euroskepticism and its development in two ways. First, specific constructions of the past have an impact on contemporary understandings of European integration. This, for instance, becomes apparent when looking at the British narrative, in which sovereign Britain is continuously challenged by the EU. Spiering (2015) shows that the 
British island discourse dating back to the 16th century has had a lasting impact on British approaches to Europe today. This concerns in particular the idea that Europe is seen as having two faces: the "good" Europe of arts and culture and the "bad" Europe of governance and social structure.

A second way in which a historical perspective adds to our understanding of contemporary Euroskepticism, is by emphasizing that the nature of European integration has changed but also that it has always gone through difficult phases (Dinan, 2014). In fact, while Euroskepticism is widely seen as having become increasingly visible since the Maastricht Treaty, criticism about and opposition to European integration has always been present (Crespy \& Verschueren, 2009). Before Maastricht, Euroskepticism may have been largely confined to the political fringes, yet this is not the full story. As such, there has never been a progressive development toward more "Europe." Also, even though many countries joined the EU and its predecessors, others decided to refrain from membership (most prominently Norway and Switzerland), and territories left well before Britain decided to leave (such as Greenland in 1985).

As Leconte (2010) explains, integration was never fully accepted, not even by mainstream politicians who were critical about several aspects of European integration during the 1940s and 1950s. For instance, Social-Democratic politicians feared that economic integration would result in social devaluation, whereas Liberal politicians feared that new European regulations would go at the expense of the free market. While German politicians feared that European integration might prevent future German unification, Dutch politicians were afraid that integration might go at the expense of transatlantic ties. Indeed, doubts about (certain aspects of) European integration were raised in all founding members and even put a hold on certain steps toward further integration, such as the European Defence Community (proposed and halted by the French in the early 1950s).

The 1973 enlargement saw the accession of three countries that were even more critical of European integration, namely Denmark, Ireland, and the United Kingdom. The first British referendum on membership of the European Community on June 5, 1975, is a good illustration of this more critical approach. The referendum was preceded by new negotiations on the terms of membership, just like in the run-up to the 2016 referendum. No less than $67.23 \%$ of voters favored continued membership. Among the supporters of a "yes" vote during the 1975 campaign in the United Kingdom was the new leader of the British Conservatives, Margaret Thatcher, who later came to be seen as the main representative of Euroskepticism. Thatcher was in favor of membership, in particular because of its economic benefits. At the same time, she was critical of steps that would lead to stronger institutions and a more federal construct, as this would curb free trade and British sovereignty (Fontana \& Parsons, 2015).

As such, Thatcher's discourse on European integration contains clear elements from the broader British narrative mentioned before, namely of the "good" versus the "bad" Europe. Thatcher's views were most (in)famously expressed during her 1988 speech at the College of Bruges, ironically one of the centers of pro-European thought. In her speech, which can be watched in full online <https://www.youtube.com/watch? $v=w k R w M F y 0 C V M>$, she underlined her rejection of European institution-building and argued that the European Community was 
"not an end in itself" (Thatcher, 1988). As Usherwood and Startin (2013) write, it was this speech that helped shape Euroskepticism in a "meaningful, mainstream way" (p. 3). It was also at this time that the word "Euroskepticism" was first used in the British press.

While Thatcher's views in the short run resulted in her resignation in November 1990, her ideas gradually caught on among British Conservatives and beyond. Criticism and opposition also became more visible across Europe after the Maastricht Treaty of 1991. This treaty was a key turning point in terms of public debate and support for European integration (e.g., Barth \& Bijsmans, 2018; Usherwood \& Startin, 2013). Maastricht constituted a considerable deepening of integration, with the establishment of a Common Foreign and Security Policy, important steps toward the creation of a common currency, the establishment of European Citizenship, and so on. The ensuing ratification crisis, with a narrow "yes" in France and a narrow "no" and the need for a second referendum in Denmark, but also the German Constitutional Court's ruling that a transfer of power should not go at the expense of democracy and constitutional rights, highlighted a shift from a "permissive consensus" to a "constraining dissensus" (Hooghe \& Marks, 2009). In other words, public support for European integration can no longer be taken for granted.

Referendums at other occasions have accentuated this shift in public opinion and have proven to be a fertile ground for Euroskeptic mobilization (Oppermann, 2018; Usherwood, 2017). The economic and Eurozone crises, the migration crisis, and, of course, Brexit, have further highlighted the development toward a more critical engagement with European affairs (Taggart \& Szczerbiak, 2018). The Eurozone crisis led Vasilopoulou (2013) to conclude that "widespread opposition to, doubts or reservations about the EU project have become a structural factor of the latter" (p. 162). This is what makes today's situation different from earlier phases in European integration history. As Hobolt (2016) writes in her study of the Brexit vote, while similar exit referendums are quite unlikely in other member states (partly due to Brexit itself; see also de Vries, 2018), citizens across the EU are divided and "the rise of populist Eurosceptic parties nonetheless presents a significant challenge to the EU" ( $p$. 1273). Not only can politicians no longer rely on public support; they have to factor in an important role for citizens, without whom further integration is no longer possible (de Vries, 2018; van Middelaar, 2016).

\section{Euroskepticism: A Problematic Concept}

While criticism on and opposition to European integration and policies have been around since the 1950s, it was not until the 1980s that the word "Euroskepticism" was first used. The increased use of the term since the 1980s has also come with an increasingly blurred meaning, one that, however, always seems to stand for a negative view on Europe (Crespy \& Verschueren, 2009, p. 383; Leruth, Startin, \& Usherwood, 2018, p. 4). As Usherwood (2013) writes, "[i]t is tempting to think of those opposed to the European integration process as an uninformed and undifferentiated group of people, a thought best summed up in the pejorative connotations in the overly reductive term 'eurosceptic'” (p. 280).

Scholarly work has, however, tried to make more sense of this "plastic notion" (Leconte, 2010, p. 5). Taggart's (1998) seminal article "A Touchstone of Decent" provided a first definition of Euroskepticism. Since then Taggart and Szczerbiak (2008) have further improved this 
definition (see also Szczerbiak \& Taggart, 2018). Their distinction between "soft" and "hard" Euroskepticism is widely referred to. Hard Euroskepticism refers to "principled opposition" to the EU and to the integration process. Parties that follow this line reject European integration and aim for withdrawal from the EU. In contrast, soft Euroskepticism does not entail the outright rejection of European integration but rather refers to "qualified opposition." This would apply to parties that are in favor of some kind of European integration but object to its current trajectory leading to a further extension of competences.

The distinction between soft and hard Euroskepticism has formed the foundation for other work on Euroskepticism. Yet, these definitions have also received their fair share of criticism. Kopecký and Mudde (2002) argue that the definitions put forward by Taggart and Szczerbiak (2008) are too broad and criteria are unclear. This particularly concerns soft Euroskepticism, which is too inclusive (cf. Szczerbiak \& Taggart, 2018). Kopecký and Mudde also note that these categories do not take into account that parties may have different ideas about, on the one hand, the idea of integration in general and, on the other hand, what the EU actually looks like. Referring to differences between diffuse and specific support, they propose four categories instead: Euro-enthusiasts, Euroskeptics, Europragmatists, and Eurorejects. Euroskeptics in this categorization "support the general ideas of European integration, but are pessimistic about the EU's current and/or future reflection of these ideas" (p. 302). Kopecký and Mudde's Europragmatists constitute a somewhat surprising category, as they may object to European integration but still support the EU for pragmatic reasons.

In another, often-cited paper, Flood (2002) does not only criticize the work of Taggart and Szczerbiak (2008) for being too crude but also argues that the work of Kopecký and Mudde (2002) is not sensitive enough toward the diversity of positions on the EU and European integration. Flood therefore introduces six different categories, ranging from a rejectionist position that opposes EU membership or participation in a policy or institution to a maximalist position that supports more integration overall or with respect to a certain policy. In other words, the positions can apply to European integration but also to EU policies.

The aforementioned conceptualizations were mainly developed within the context of party politics. Another often-mentioned conceptualization has been developed within the context of public opinion research. Krouwel and Abts (2007) start from the assumption that Kopecký and Mudde's (2002) categories are still not precise enough. Different arguments as well as different degrees of opposition should be taken into account, resulting in a five-step scale of attitudes toward European integration, with Euroconfidence being the most positive attitude and Euro-alienation the most negative. In their categorization, Euroskepticism does not equal rejection of the EU or European integration but is rather "a trade-off between some dissatisfaction with current EU performance and confidence in the overall project of European integration" (p. 262).

There clearly is no commonly accepted definition of Euroskepticism. Krouwel and Abts (2007), in fact, maintain that skepticism is usually seen as "a matter of doubt rather than denial" ( $p$. 259), which can be viewed as a normal element of political engagement. Interestingly, the categories proposed by Flood (2002) do not even include the words "Euroskepticism" or "skepticism." The absence of a commonly accepted definition is partly due to the EU's complex and ever-changing nature. There is also the question of whether Euroskepticism is related to existing cleavages in politics or constitutes a new one (e.g., Börzel \& Risse, 2009; 
Hooghe \& Marks, 2009). In addition, Euroskepticism's relation to the rise of populist challenger parties across Europe and the concept of populism itself constitutes another complication (e.g., Leconte, 2015; Ruzza, 2009). Hence, some scholars have problematized the use of the concept of Euroskepticism altogether.

Harmsen (2010), for instance, points at the need to distinguish between "genuine oppositions to European integration and that which might more reasonably be regarded as a normal (and desirable) politicization of European issues within the framework of a multi-level polity" ( $p$. 336; emphasis in the original). Crespy and Verschueren (2009) argue for using the term "resistance" instead, as it offers more analytical value. Leconte (2015) highlights the importance of moving beyond pro/con distinctions and soft and hard Euroskepticism, as this better captures the fact that Europe means different things to different people.

We may ask whether the term "Euroskepticism" is still useful. Yet, at the same time we need such models and conceptualizations to make sense of reality. Vasilopoulou (2013) concludes that it all boils down to "how 'inclusive' or 'exclusive' one seeks to be" (p. 156). Szczerbiak and Taggart (2008) warn that "the more complex and fine-grained the typology, the more difficult it is to operationalize and categorize" (p. 246). In other words, whereas a pro/con dichotomy or Taggart and Szczerbiak's (2018) soft and hard Euroskepticism may offer too little scope for researching the range of opinions about the EU and its policies, those proposed by, for instance, Flood (2002), Kopecký and Mudde (2002), and Krouwel and Abts (2007) may be difficult to apply due to the challenge of having to empirically differentiate between several positions.

\section{Euroskepticism: National Political Parties, Public Opinion, and Beyond}

Given the broad nature of Euroskepticism, it is no surprise that different approaches have been used to study it (see Mudde, 2012). Much of the early work focused on Euroskepticism as expressed by political parties and public opinion. This research has been important in terms of establishing the research field. Yet, it is also limited in its scope and perspective. The focus is often on institutions and integration, with policies rarely studied. In addition, qualitative work is underrepresented, and interdisciplinary perspectives are largely absent (Hobolt \& de Vries, 2016; Szczerbiak \& Taggart, 2018; Vasilopoulou, 2018a), hence the calls for broadening the scope of research to other fields, especially now that Euroskepticism has become embedded in contemporary Europe (Crespy \& Verschueren, 2009; Usherwood \& Startin, 2013).

This section consist of two parts. I first discuss research into national parties and public opinions. Taggart and Szczerbiak's (2008) work referred to earlier has been particularly important in shaping our understanding of Euroskepticism and has been the basis for many studies that have looked at party positions toward the EU. As for public opinion research, the European Commission has been publishing Eurobarometer polls since the 1970s. With the democratic nature of the EU being increasingly questioned since the early 1990s, scholars also became increasingly interested in public opinion toward the EU. In the second part of this section I broaden the scope beyond national parties and public opinion by looking at work that has explored Euroskepticism from interpretative and interdisciplinary angles. I particularly look at research into media coverage and into the development of a transnational Euroskepticism. 


\section{Political Parties and Public Opinion}

It has long been believed that Europe hardly had an impact on party systems. Despite the fact that parties were at times reluctant towards certain elements of the integration process, the issue was generally avoided, partly due to fear of internal divisions. Party political Euroskepticism was a phenomenon limited to the fringes of the political system or to singleissue parties, despite the gradual emergence of a more EU-critical attitude (e.g. Mair, 2000; Ray, 2007). Today, this position has become difficult to maintain, as mainstream parties increasingly voice criticism about EU policies, future enlargement and institutional reform.

Research on political parties and Euroskepticism has looked at European integration and the EU's institutional set-up in particular. Two explanations for party-political Euroskepticism have dominated the debate. The first explanation centers on ideology. The key argument here is that parties' position on the political spectrum determines their stance on Europe (e.g., Hooghe, Marks, \& Wilson, 2002; Kopecký \& Mudde, 2002). Parties close to the political center are less likely to be Euroskeptic than parties on the fringes. The former have been responsible for the course of early stages of integration and will tend to be supportive of it. Hooghe and colleagues have called this the "inverted U curve."

It is important to note in this context that this research also suggests that European integration does not neatly fit into existing cleavages. This makes it more difficult to explain why parties on different sides of the political spectrum share largely similar ideas about it. A second proposition has therefore centred on strategy as the key reason for Euroskeptic positions (e.g., Sitter, 2001; Taggart, 1998). Parties resort to Euroskeptic positions within the context of domestic politics and government-opposition dynamics. Such strategic motives also become clear when more radical parties end up in a position where they may enter government. Many actually have had to change their tone on EU politics; Syriza in Greece is a good example (Topaloff, 2018, pp. 71-72; Vasilopoulou, 2018b).

Euroskepticism was long seen as limited to fringe parties. Yet, new questions have emerged with regard to the changing stance of mainstream political parties, which have become more vocal in their criticism of the EU and its policies (Rohrschneider \& Whitefield, 2016; Vasilopoulou, 2018b). Part of this criticism is of a strategic nature, with politicians claiming credit for EU policies supported at home or blaming Brussels for unpopular policy choices. According to Topaloff (2018), this strategy has undoubtedly contributed to the rise of populist Euroskeptic parties and an increasingly critical electorate.

Indeed, while European integration has long been an elite-driven process, public opinion on the EU has seen a shift to what Hooghe and Marks (2009) have called a "constraining dissensus." This refers to the fact that an ever more critical electorate entails that politicians can no longer engage in European affairs without taking into account public opinion. Public support for the EU and Euroskepticism are two sides of the same coin, with the latter having become the dominant subject of research during the past 10 to 15 years. A number of possible explanations of EU public opinion reoccur in the literature: the role of utilitarian motives, identity, and the evaluation of national politics (e.g., Guerra \& McLaren, 2016; Hobolt \& de Vries, 2016). 
Studies that focus on utilitarian factors assume that citizens will support the EU either when they personally benefit or when their country benefits (e.g., Eichenberg \& Dalton, 1993; Gabel $\&$ Whitten, 1997). The latter perspective looks at national economic performance and questions related to the benefits of being an EU member. Some countries benefit more from the EU budget than others, and it is claimed that citizens of those countries will be more likely to see EU membership as a good thing. When looking at the level of the individual, socioeconomic status is the key focus. Generally, the assumption is that individuals with a certain background (e.g., young and highly educated) will benefit more than others and, hence, will be more supportive of the EU and European integration.

One of the challenges to the utilitarian perspective concerns the fact that a growing economy does not necessarily prevent a rise in Euroskepticism, as could be seen during the 1990s. Scholars therefore looked at other possible explanations, including European identity, identification with the EU, and the extent to which national identities affect support for the EU (e.g., Carey, 2002; Hooghe \& Marks, 2005). This research suggests that if European integration is seen as conflicting with national identity, this may result in more negative opinions. As identities are not necessarily mutually exclusive, Hooghe and Marks look at the extent to which people have exclusive national identities. The more exclusive one's national identity, the least likely one is to identify with Europe.

A final perspective on EU public opinion and Euroskepticism is concerned with its interplay with evaluations of domestic government (e.g., Anderson, 1998; Franklin, van der Eijk, \& Marsh, 1995). This research looks into whether trust in domestic government or lack thereof has a, respectively, positive or negative impact on people's attitudes toward the EU. This serves as guidance to citizens who tend to be less aware of EU affairs. Hence, scholars have also looked into how citizens' opinions may be shaped, with political parties and media being seen as important providers of information (e.g., de Vreese, 2007).

Recent research by de Vries $(2017,2018)$ suggests that these three main perspectives may be limited in terms of their explanatory value regarding the more recent rise of Euroskepticism. Instead, she proposes what she calls a "benchmark theory of EU public opinion" that postulates that people determine their opinion by evaluating what appears to be more tempting: the status quo of EU membership versus leaving the EU. De Vries explains that this may be an important explanation for the rise of support for the EU since Brexit. She also identifies different forms of skepticism that vary in prominence depending on member states' quality of government and economic performance.

\section{Euroskepticism Beyond National Parties and Publics}

De Vries' $(2017,2018)$ research is important not only because of its new insights into public opinion in an age of Brexit but also because she explicitly refers to polity and policy. This highlights the need to address Euroskepticism in different ways, including interdisciplinary and interpretative perspectives. Leconte (2015; cf. Daddow, 2015) argues that it is worthwhile studying Euroskepticism as a discourse, as a way to gain better insight into the varieties of criticism on and opposition toward the EU and its policies. Since discourse often takes shape in media debates, it is worth looking at how the media cover debates about EU affairs and what this entails for Euroskepticism (e.g., Caiani \& Guerra, 2017; Michailidou, 2018). 
Lloyd and Marconi (2014, p. 68) explain that journalistic attempts to make the EU more understandable and exiting are often based on an approach in which member states are generally pitted against each other rather than as acting together in EU decision-making. Yet, this has also resulted in a more critical and skeptical approach toward the EU; the authors therefore call Euroskepticism a "by-product of the lack of clarity" (p. 74). Leconte (2010) also argues that apparent deficiencies in media reporting may stimulate Euroskepticism, as European politics are only discussed in a national context with fairly limited attention for the European level and for related developments in other member states. In addition, stereotypes can also be an important source for misrepresentation of European politics (e.g., Breeze, 2014; Daddow, 2012).

The anti-European stance of parts of the British press is well documented (e.g., Daddow, 2012; Startin, 2015), but scholars have also studied media and Euroskepticism in other European countries. These studies have picked up on different forms of criticism on and opposition to the EU and its policies. In his analysis of Austrian Euroskepticism, Karner (2013) argues, among other things, that Austrian quality media include alternative evaluations of European affairs. Based on a claim-making analysis of political party positions as covered by the media, Statham, Koopmans, Tresch, and Firmstone (2010, p. 271) argue that certain aspects of the EU and its policies are criticized and alternatives are put forward, but integration as such is not questioned. Statham and Trenz (2013) refer to so-called Eurocritical claims to describe claims that are based on alternative visions of Europe, rather than an outright rejection of any form of European integration. The prominence of these types of claims may indicate a normalization of EU politics.

Earlier studies on media reporting and Euroskepticism often revolved around the question whether news media coverage of EU affairs is predominantly negative or positive. Yet, recently new typologies have been put forward that acknowledge that opinions for and against European integration and EU policies are two sides of the same coin and come in many different guises (e.g., Bijsmans, 2017; de Wilde, Michailidou, \& Trenz, 2013; Startin, 2015). While important, this does not make easier attempts toward conceptual clarification and methodological applicability.

Research on EU media coverage often takes a transnational perspective, as scholars are interested in whether debates and opinions cross national borders and help foster a European public sphere. For instance, Gattermann and Vasilopoulou (2017) studied whether we may be witnessing the emergence of a "Eurosceptic public sphere" in which national newspapers pay increased attention to Euroskeptic candidates from other countries. Comparing the 2009 and 2014 European elections, they find that attention for Euroskeptic candidates has increased, but this predominantly concerns national Euroskeptics. Bijsmans, Galpin, and Leruth (2018) approached the matter of a transnational Euroskepticism from a different perspective. They researched how newspapers in France, Germany, and the Netherlands covered the debate about Brexit and to what extent there was a shared conception of criticism on the EU, as well as similar views on the future of European integration. Their analysis shows that while initially British concerns were shared (in particular in Germany and the Netherlands), as the referendum drew nearer, the discourse shifted toward the importance of unity among the remaining 27 member states. 
FitzGibbon, Leruth, and Startin (2017a) make a more general case for attention for transnational Euroskepticism as "we are witnessing the emergence of a pan-European and transnational dynamic among those voices that oppose European integration" (p. 3). Focusing on transnational Euroskepticism may appear somewhat surprising; after all, why would parties and movements that reject integration and emphasize national sovereignty be tempted to work together across borders and at the European level? At the same time, we have seen an increasing tendency to cooperate in, for instance, the European Parliament (EP), which currently includes two prominent Euroskeptic groups, the European Conservatives and Reformists (which includes the British Conservatives) and the Identity and Democracy Group (with Marine Le Pen's Rassemblement National and Geert Wilders' Partij voor de Vrijheid [Party for Freedom]).

Indeed, there is quite a lot of recent research on cooperation between Euroskeptics in the EP. Brack and Costa (2018) explain that pro-European beliefs have long dominated within EU institutions due to support for the ideal of integration, as well as due to utilitarian motives. Throughout time, these beliefs became enshrined in the institutions. While this does not mean that there have not been any critical Europeans within the institution, it does mean that they normally tend not to be in a position to openly put forward their views. Also, as Dehousse and Thompson (2012) show with regard to the case of intergovernmentalists in the European Commission, their criticism does not necessarily entail that they will work against their institution.

Not only have there been sizeable groups of Euroskeptic Members of European Parliament (MEPs), but they are also offered a stage to air their views. Brack's (2018) research, however, also shows that Euroskeptics form a mixed bunch, and their heterogeneity can have an impact on their effectiveness. In fact, she has identified four distinctive role types that are taken up by Euroskeptic MEPs: absentees' involvement is low and their focus is on the national level; public orators engage in public speaking with an aim of spreading negative views on the EU; pragmatists do engage in the EPs work while not forgetting their criticism of the EU; participants fully engage with EP business in order to influence the policymaking process.

\section{Euroskepticism and Its Implications for European Politics and Democracy}

We have seen that Euroskepticism has become much more prominent in recent years and has manifested itself in many different ways. But what about Euroskepticism's wider implications for European politics and democracy? Usherwood, Leruth, and Startin (2018) identify two competing views. The first emphasizes Euroskepticism's negative connotation and considers it to be a problem for European integration. It limits the options for further integration and can even lead to a struggle that may result in disintegration. The second view of Euroskepticism adopts a broader perspective on criticism and opposition and considers it to be part and parcel of democratic politics. In an EU that has long been seen as an elite project, this may actually help open up debates to political demands from citizens.

Research shows that Europe has become increasingly salient and that Euroskepticism affects national and European politics. An obvious consequence of the rise of Euroskepticism has been the increase of the number of Euroskeptic MEPs, from 151 at the start of the 2009-2014 
legislative term to 229 at the start of the 2014-2019 legislative term (Brack, 2018). European elections were long seen as second-order affairs, dominated by domestic politics and protestvoting (Reif \& Schmitt, 1980). However, recent research suggests that European issues have increasingly come to play a role. For instance, Hobolt, Spoon, and Tilley (2009) show that voters tend to be more skeptical toward the EU than mainstream governing parties and, hence, opt for parties that are also more Euroskeptic.

At the national level, Europe was also long seen as a non-issue (Mair, 2000). In fact, studies of the 2017 national elections in Germany (Schoen, 2019) and the Netherlands (van Holsteyn, 2018) maintain that Europe was hardly an issue. Yet, other studies argue differently. For instance, following an analysis of elections in Austria, Britain, France, Germany, and Switzerland between 1970 and 2010, Hutter and Grande (2014) conclude that European integration has been increasingly politicized, either due to populist parties or as a result of debates among mainstream parties. Similarly, de Vries (2007) argues that EU issue voting occurs in national elections, in particular in countries where there is party competition over European integration and the issue is salient among voters. The rise of populist, Euroskeptic parties is telling and has resulted in increasingly fragmented party systems, including in countries that have long been characterized by a two-party system, such as Spain.

Euroskepticism influences how member states respond to EU policies, as can, for instance, be seen when looking at Hungarian and Italian governments' stance toward EU migration policy. Hagemann, Bailer, and Herzog (2019) and Hagemann, Hobolt, and Wratil (2017) show how Euroskepticism influences national government's engagement in the Council of Ministers. When parliament has a strong control function and the political sphere is fragmented, governments want to show their responsiveness through votes and statements in the Council (Hagemann et al., 2019). When domestic electorates are skeptical and European integration is a prominent issue in domestic politics, governments might oppose legislation that concerns the transfer of authority to the EU (Hagemann et al., 2017). This may not put a stop to EU legislation, but it serves as a signal that shows that governments are responsive to their citizens.

Galpin and Trenz (2017) refer to a "spiral of Euroskepticism" to highlight the role of negative media coverage on Euroskepticism. Van Spanje and de Vreese (2014) argue that media coverage of the EU influenced voting for Euroskeptic parties during the 2009 European elections. Voters who were confronted with more negative media evaluation of the EU were more likely to vote for Euroskeptic parties, while voters who were exposed to the so-called benefit framing of the EU were less likely to vote for such parties. Similar findings have been reported by Hobolt, Spoon, and Tilley (2009) in their study on the 1999 and 2004 European elections.

Others have looked at media coverage of Euroskepticism from the perspective of its implications for a European public sphere. Earlier I referred to Gattermann and Vasilopoulou's (2017) research on the emergence of a "Euroskeptic public sphere" as an important counternarrative in the context of EU democracy. They argue that the presence of this counternarrative is important for democratic public debates about EU affairs. Similarly, Hagemann et al. (2017, pp. 867-869) show that governments' responsiveness to their citizens in the Council of the European Union is also picked up by national media, opening up EU politics to a wider audience. 
Dutceac Segesten and Bossetta (2019) also look at Euroskepticism's importance in light of the development of a European public sphere. They show that Euroskepticism contributes to the Europeanization of national public spheres, especially in broadsheet newspapers. Coverage of British Euroskepticism is a particular focal point across public spheres, but British media coverage of developments in other countries is almost absent. The latter, the authors argue, may have been important in light of the Brexit debate (p. 12). Indeed, Startin (2015) notes the important role played by British media-tabloids in particular-in creating an environment in which hostility toward the EU became commonplace.

This debate about media coverage of EU affairs and Euroskepticism is linked to the more general debate about EU democracy. According to Follesdal and Hix (2006), the main problem with regard to the so-called democratic deficit is not of an institutional nature but one of missing democratic contestation about the EU and its policies. Yet, Euroskepticism is leading to more contestation. When reducing Euroskepticism to a purely rejective phenomenon, this may be seen as a negative development that endangers the functioning and development of the EU and might even lead to "the end of European integration" (cf. Taylor, 2008). Yet, Euroskeptic voices may also stimulate politicization in a positive way by triggering proEuropean voices to put forward arguments in defense of the European project (e.g., Gattermann \& Vasilopoulou, 2017; Michailidou, 2018).

More importantly, we have seen that Euroskepticism represents a range of positions that includes alternative conceptions of the EU and its policies. This form of criticism-as opposed to being against the EU-was also present in crises-stricken countries (e.g., Bourne \&

Chatzopoulou, 2018; Clements, Nanou, \& Verney, 2014). Euroskeptics on the right and the left are both critical but have different views on what constitutes a better Europe (Hobolt, 2015; Hobolt \& Tilley, 2016). Not only does this present voters with options, but we have also seen that citizens' preferences regarding the EU are picked up by their political representatives.

Of course, this does not automatically make EU politics democratic. For instance, whether Euroskeptic opinion plays a role in the European Parliament depends on the extent to which Euroskeptic MEPs engage with and are offered a platform in European politics (Brack, 2018; Treib, 2014). Also, it is challenging for European elites to cater to the diversity of opinions and positions (cf. de Vries, 2018). Nevertheless, seen from this wider perspective, Euroskepticism could be dubbed as a "healthy scepticism" (Milner, 2000) that stimulates political debates and a gradual normalization of EU politics.

\section{Conclusion}

EU policymaking has become much more prominent in mediated public debates. For example, the Eurozone crisis was characterised by lively debates on the question of austerity versus investment. The migration crisis, for its part, resulted in heated debates about Europe's borders, state sovereignty, and so on. Furthermore, Brexit stimulated a more general debate about the future of European integration and the implications of Euroskepticism.

I aimed to provide an encompassing view of what Euroskepticism is and how it is manifested in contemporary Europe. I have illustrated that Euroskepticism is a diverse, multifaceted phenomenon. The brief history of Euroskepticism has already shown that Euroskepticism is 
not something new but has been present since the start of the integration process. Other research reports the existence of varying ideas on Europe among citizens and parties and representations in media and transnational institutions and organizations.

This does in no way mean that we should downplay Euroskepticism. Yet, it does force us to think about what it entails beyond its mere negative, rejectionist connotation. A broader, interdisciplinary research agenda allows us to reach a better insight into not just what Euroskepticism actually entails but also how it is manifested in different contexts and what implications it may have. Yet, the need for a broader, interdisciplinary research agenda does not only follow from the need to better understand Euroskepticism. It is also important in light of European democracy and the need to factor in the different ideas expressed by Europeans.

The fact that debate about the EU and its policies is not new should eliminate worries that a critical citizenry is problematic per se. There has always been debate about European integration and policies, and criticism and objections have been taken into account throughout. This has not stopped the development of the EU. In sum, Euroskepticism has had an impact on the EU, and its diverse manifestation may result in a much-needed debate and certainly does not automatically signal the end European integration.

\section{References}

Anderson, C. J. (1998). When in doubt, use proxies: Attitudes toward domestic politics and support for European integration. Comparative Political Studies, 31(5), 569-601.

Barth, C., \& Bijsmans, P. (2018). The Maastricht Treaty and public debates about European integration: The emergence of a European public sphere? Journal of Contemporary European Studies, 26(2), 215-231.

Bijsmans, P. (2017). EU media coverage in times of crisis: Euroscepticism becoming mainstream? In M. Caiani \& S. Guerra (Eds.), Euroscepticism, democracy and the media: Communicating Europe, contesting Europe (pp. 73-94). Basingstoke, U.K.: Palgrave Macmillan.

Bijsmans, P., Galpin, C., \& Leruth, B. (2018). "Brexit" in transnational perspective: An analysis of newspapers in France, Germany and the Netherlands. Comparative European Politics, 16(5), 825-842.

Börzel, T. A., \& Risse, T. (2009). Revisiting the nature of the beast-politicization, European identity, and postfunctionalism: A comment on Hooghe and Marks. British Journal of Political Science, 39(1), 217-220.

Bourne, A., \& Chatzopoulou, S. (2018). Euroscepticism and the crisis: "Critical Europeanism" and anti-austerity movements. In B. Leruth, N. Startin, \& S. Usherwood (Eds.), The Routledge handbook of Euroscepticism (pp. 306-316). London, U.K.: Routledge.

Brack, N. (2018). Opposing Europe in the European Parliament: Rebels and radicals in the chamber. London, U.K.: Palgrave Macmillan.

Brack, N., \& Costa, O. (2018). Euroscepticism in the EU institutions. A persistent and embedded phenomenon. In N. Startin, S. Usherwood, \& B. Leruth (Eds.), The Routledge handbook of Euroscepticism (pp. 371-381). London, U.K.: Routledge. 
Brack, N., \& Startin, N. (2015). Introduction: Euroscepticism, from the margins to the mainstream. International Political Science Review, 36(3), 239-249.

Breeze, R. (2014). Perspectives on North and South: The 2012 financial crisis in Spain seen through two major British newspapers. Discourse \& Communication, 8(3), 241-259.

Caiani, M., \& Guerra, S. (Eds.). (2017). Euroscepticism, democracy and the media.

Communicating Europe, contesting Europe. Basingstoke, U.K.: Palgrave Macmillan.

Carey, S. (2002). Undivided loyalties: Is national identity an obstacle to European integration? European Union Politics, 3(4), 387-413.

Clements, B., Nanou, K., \& Verney, S. (2014). “We no longer love you, but we don't want to leave you": The Eurozone crisis and popular Euroscepticism in Greece. Journal of European Integration, 36(3), 247-265.

Crespy, A., \& Verschueren, N. (2009). From Euroscepticism to resistance to European integration: An interdisciplinary perspective. Perspectives on European Politics and Society, 10(3), 377-393.

Daddow, O. (2012). The UK media and "Europe": From permissive consensus to destructive dissent. International Affairs, 88(6), 1219-1236.

Daddow, O. (2015). Interpreting the outsider tradition in British European policy speeches from Thatcher to Cameron. Journal of Common Market Studies, 53(1), 71-88.

Dehousse, R., \& Thompson, A. (2012). Intergovernmentalists in the Commission: Foxes in the henhouse? Journal of European Integration, 34(2), 113-132.

de Vreese, C. H. (2007). A spiral of Euroscepticism: The media's fault? Acta Politica, 42(2-3), $252-270$

de Vries, C. E. (2007). Sleeping giant: Fact or fairytale? How European integration affects national elections. European Union Politics, 8(3), 363-385.

de Vries, C. E. (2017). Benchmarking Brexit: How the British decision to leave shapes EU public opinion. Journal of Common Market Studies, 55(Suppl. 1), 38-53.

de Vries, C. E. (2018). Euroscepticism and the future of European integration. Oxford, U.K.: Oxford University Press.

de Wilde, P., Michailidou, A., \& Trenz, H.-J. (2013). Contesting Europe: Exploring Euroscepticism in online media coverage. Colchester, U.K.: ECPR Press.

Dinan, D. (2014). Europe recast: A history of European Union (2nd ed.). Basingstoke, U.K.: Palgrave Macmillan.

Dutceac Segesten, A., \& Bossetta, M. (2019). Can Euroscepticism contribute to a European public sphere? The Europeanization of media discourses on Euroscepticism across six countries <https://onlinelibrary.wiley.com/doi/abs/10.1111/jcms.12871>.Journal of Common Market Studies, 57(5), 1051-1070. 
Eichenberg, R. C., \& Dalton, R. J. (1993). Europeans and the European Community: The dynamics of public support for European integration. International Organization, 47(4), 507534.

European Parliament. (2018). Democracy on the move: European elections-one year to go. Brussels, Belgium: Publications Office of the European Union.

FitzGibbon, J., Leruth, B., \& Startin, N. (2017a). Introduction. In J. FitzGibbon, B. Leruth, \& N. Startin (Eds.), Euroscepticism as a transnational and Pan-European phenomenon: The emergence of a new sphere of opposition (pp. 1-13). London, U.K.: Routledge.

FitzGibbon, J., Leruth, B., \& Startin, N. (Eds.). (2017b). Euroscepticism as a transnational and Pan-European phenomenon: The emergence of a new sphere of opposition. London, U.K.: Routledge.

Flood, C. (2002, September). Euroscepticism: A problematic concept <http://www.uaces.org/ documents/papers/0201/flood.pdf $>$. Paper presented at the UACES Annual Conference, Belfast, U.K.

Follesdal, A., \& Hix, S. (2006). Why there is a democratic deficit in the EU: A response to Majone and Moravcsik. Journal of Common Market Studies, 44(3), 533-562.

Fontana, C., \& Parsons, C. (2015). “One woman's prejudice”: Did Margaret Thatcher cause Britain's anti-Europeanism? Journal of Common Market Studies, 53(1), 89-105.

Franklin, M. N., van der Eijk C., \& Marsh, M. (1995). Referendum outcomes and trust in government: Public support for Europe in the wake of Maastricht. West European Politics, 18(3), 101-117.

Gabel, M., \& Whitten, G. D. (1997). Economic conditions, economic perceptions and public support for European integration. Political Behavior, 19(1), 81-96.

Galpin, C., \& Trenz, H.-J. (2017). The spiral of Euroscepticism: Media negativity, framing and opposition to the EU. In M. Caiani \& S. Guerra (Eds.), Euroscepticism, democracy and the media. Communicating Europe, contesting Europe (pp. 49-72). Basingstoke, U.K.: Palgrave Macmillan.

Gattermann, K., \& Vasilopoulou, S. (2017). Eurosceptic candidate MEPs in the news: A transnational perspective. In J. FitzGibbon, B. Leruth, \& N. Startin (Eds.), Euroscepticism as a transnational and Pan-European phenomenon: The emergence of a new sphere of opposition (pp. 130-146). London, U.K.: Routledge.

George, S. (1998). An awkward partner: Britain in the European Community (3rd ed.). Oxford, U.K.: Oxford University Press.

Guerra, S., \& McLaren, L. M. (2016). Public opinion and the European Union. In M. Cini \& N. Perez-Solorzano Borragan (Eds.), European Union politics (5th ed., pp. 352-364). Oxford, U.K.: Oxford University Press.

Hagemann, S., Bailer, S., \& Herzog, A. (2019). Signals to their parliament? Governments' use of votes and policy statements in the EU Council. Journal of Common Market Studies, 57(3), 634650. 
Hagemann, S., Hobolt, S. B., \& Wratil, C. (2017). Government responsiveness in the European Union. Comparative Political Studies, 50(6), 850-876.

Halikiopoulou, D. (2018). A right-wing populist momentum? A review of 2017 elections across Europe. Journal of Common Market Studies, 56(Suppl. 1), 63-73.

Harmsen, R. (2010). Concluding comment: On understanding the relationship between populism and Euroscepticism. Perspectives on European Politics and Society, 11(3), 333-341.

Hix, S. (2018). Brexit: Where is the EU-UK relationship heading? Journal of Common Market Studies, 56(Suppl. 1), 11-27.

Hobolt, S. B. (2015). The 2014 European Parliament elections: Divided in unity? Journal of Common Market Studies, 53(Suppl. 1), 6-21.

Hobolt, S. B. (2016). The Brexit vote: A divided nation, a divided continent. Journal of European Public Policy, 23(9), 1259-1277.

Hobolt, S. B., \& de Vries, C. E. (2016). Public support for European integration. Annual Review of Political Science, 19, 413-432.

Hobolt, S. B., Spoon, J.-J., \& Tilley, J. (2009). A vote against Europe? Explaining defection at the 1999 and 2004 European Parliament elections. British Journal of Political Science, 39(1), 93115.

Hobolt, S. B., \& Tilley, J. (2016). Fleeing the centre: The rise of challenger parties in the aftermath of the euro crisis. West European Politics, 39(5), 971-991.

Hooghe, L., \& Marks, G. (2005). Calculation, community and cues: Public opinion on European integration. European Union Politics, 6(4), 419-43.

Hooghe, L., \& Marks, G. (2009). A postfunctionalist theory of European integration: From permissive consensus to constraining dissensus. British Journal of Political Science, 39(1), 1-23.

Hooghe, L., Marks, G., \& Wilson, C. J. (2002). Does left/right structure party positions on European integration? Comparative Political Studies, 35(8), 965-989.

Hutter, S., \& Grande, E. (2014). Politicizing Europe in the national electoral arena: A comparative analysis of five west European countries, 1970-2010. Journal of Common Market Studies, 52(5), 1002-1018.

Karner, C. (2013). Europe and the nation: Austrian EU-scepticism and its contestation. Journal of Contemporary European Studies, 21(2), 252-268.

Kopecký, P., \& Mudde, C. (2002). The two sides of Euroscepticism: Party positions on European integration in East Central Europe. European Union Politics, 3(3), 297-326.

Krouwel, A., \& Abts, K. (2007). Varieties of Euroscepticism and populist mobilization: Transforming attitudes from mild Euroscepticism to harsh Eurocynicism. Acta Politica, 42(2-3), 252-270.

Leconte, C. (2010). Understanding Euroscepticism. Basingstoke, U.K.: Palgrave Macmillan. 
Leconte, C. (2015). From pathology to mainstream phenomenon: Reviewing the Euroscepticism debate in research and theory. International Political Science Review, 36(3), 250-263.

Leruth, B., Startin, N., \& Usherwood, S. (2018). Defining Euroscepticism: From a broad concept to a field of study. In B. Leruth, N. Startin, \& S. Usherwood (Eds.), The Routledge handbook of Euroscepticism (pp. 3-10). London, U.K.: Routledge.

Lloyd, J., \& Marconi, C. (2014). Reporting the EU: News, media and the European institutions. London, U.K.: I. B. Tauris.

Lubbers, M., \& Scheepers, P. (2010). Divergent trends of Euroscepticism in countries and regions of the European Union. European Journal of Political Research, 49(6), 787-817.

Mair, P. (2000). The limited impact of Europe on national party systems. West European Politics, 23(4), 27-51.

Michailidou, A. (2018). Mirroring or setting the political agenda? The role of the media in the Eurosceptic debate. In B. Leruth, N. Startin, \& S. Usherwood (Eds.), The Routledge handbook of Euroscepticism (pp. 344-356). London, U.K.: Routledge.

Milner, S. (2000). Introduction: A healthy scepticism? Journal of European Integration, 22(1), 113.

Mudde, C. (2012). The comparative study of party-based Euroscepticism: The Sussex versus the North Carolina School. East European Politics, 28(2), 193-202.

Oppermann, K. (2018). Derailing European integration? Euroscepticism and the politics of EU referendums. In B. Leruth, N. Startin, \& S. Usherwood (Eds.), The Routledge handbook of Euroscepticism (pp. 243-255). London, U.K.: Routledge.

Pew Research Center. (2017). Post-Brexit, Europeans more favorable toward EU. Washington, DC: Author.

Ray, L. (2007). Mainstream Euroskepticism: Trend or oxymoron? Acta Politica, 42(2-3), 153-172.

Reif, K., \& Schmitt, H. (1980). Nine second-order national elections-A conceptual framework for the analysis of European election results. European Journal of Political Research, 8(1), 3-44.

Rohrschneider, R., \& Whitefield, S. (2016). Responding to growing European Union-skepticism? The stances of political parties toward European integration in Western and Eastern Europe following the financial crisis. European Union Politics, 17(1), 138-161.

Ruzza, C. (2009). Populism and Euroscepticism: Towards uncivil society? Policy and Society, 28(1), 87-98.

Schoen, H. (2019). Not a powerful electoral issue yet: On the role of European integration in the 2017 German federal election. Journal of European Public Policy, 26(5), 717-733.

Sitter, N. (2001). The politics of opposition and European integration in Scandinavia: Is Euroscepticism a government-opposition dynamic? West European Politics, 24(4), 22-39.

Spiering, M. (2015). A cultural history of British Euroscepticism. Basingstoke, U.K.: Palgrave Macmillan. 
Startin, N. (2015). Have we reached a tipping point? The mainstreaming of Euroscepticism in the UK. International Political Science Review, 36(3), 311-323.

Statham, P., Koopmans, R., Tresch, A., \& Firmstone, J. (2010). Political party contestation. Emerging Euroscepticism or a normalization of Eurocriticism. In R. Koopmans \& P. Statham (Eds.), The making of a European public sphere: Media discourse and political contention (pp. 245-273). Cambridge, U.K.: Cambridge University Press.

Statham, P., \& Trenz, H.-J. (2013). How European Union politicization can emerge through contestation: The constitution case. Journal of Common Market Studies, 51(5), 965-980.

Szczerbiak, A., \& Taggart, P. (2018). Contemporary research on Euroscepticism: The state of the art. In B. Leruth, N. Startin, \& S. Usherwood (Eds.), The Routledge handbook of Euroscepticism (pp. 11-21). London, U.K.: Routledge.

Szczerbiak, A., \& Taggart, P. (Eds.). (2008). Opposing Europe? The comparative party politics of Euroscepticism. Vol. 1: Case studies and country surveys. Oxford, U.K.: Oxford University Press.

Taggart, P. (1998). A touchstone of dissent: Euroscepticism in contemporary Western European party systems. European Journal of Political Research, 33(3), 363-388.

Taggart, P., \& Szczerbiak, A. (2008). Introduction: Opposing Europe? The politics of Euroscepticism in Europe. In A. Szczerbiak \& P. Taggart (Eds.), Opposing Europe? The comparative party politics of Euroscepticism. Vol. 1: Case studies and country surveys (pp. 115). Oxford, U.K.: Oxford University Press.

Taggart, P., \& Szczerbiak, A. (2018). Putting Brexit into perspective: The effect of the Eurozone and migration cries and Brexit on Euroscepticism in European states. Journal of European Public Policy, 25(8), 1194-1214.

Taylor, P. (2008). The end of European integration: Anti-Europeanism examined. London, U.K.: Routledge.

Thatcher, M. (1988, September 20). Speech to the College of Europe ("The Bruges Speech") [ <https://www.margaretthatcher.org/document/107332>. Bruges, Belgium.

Topaloff, L. K. (2018). Euroscepticism and political parties: Theory and practice. In B. Leruth, N. Startin, \& S. Usherwood (Eds.), The Routledge handbook of Euroscepticism (pp. 63-74). London, U.K.: Routledge.

Treib, O. (2014). The voter says no, but nobody listens: Causes and consequences of the Eurosceptic vote in the 2014 European elections. Journal of European Public Policy, 21(10), 1541-1554.

Usherwood, S. (2013). The shifting focus of opposition to the European Union. Journal of Contemporary European Research, 9(2), 279-296.

Usherwood, S. (2017). Modelling transnational and pan-European Euroscepticism. In J. FitzGibbon, B. Leruth, \& N. Startin (Eds.), Euroscepticism as a transnational and pan-European phenomenon: The emergence of a new sphere of opposition (pp. 14-27). London, U.K.: Routledge. 
Usherwood, S., Leruth, B., \& Startin, N. (2018). Conclusion: Euroscepticism and European (dis)integration in the age of Brexit. In B. Leruth, N. Startin, \& S. Usherwood (Eds.), The Routledge handbook of Euroscepticism (pp. 468-477). London, U.K.: Routledge.

Usherwood, S., \& Startin, N. (2013). Euroscepticism as a persistent phenomenon. Journal of Common Market Studies, 51(1), 1-16.

van Holsteyn, J. J. M. (2018). The Dutch parliamentary elections of March 2017. West European Politics, 41(6), 1364-1377.

van Middelaar, L. (2016). The return of politics-The European Union after the crises in the eurozone and Ukraine. Journal of Common Market Studies, 54(3), 495-507.

van Spanje, J., \& de Vreese, C. (2014). Europhile media and Eurosceptic voting: Effects of news media coverage on Eurosceptic voting in the 2009 European Parliamentary elections. Political Communication, 31(20), 325-354.

Vasilopoulou, S. (2013). Continuity and change in the study of Euroscepticism: Plus ça change? Journal of Common Market Studies, 51(1), 153-168.

Vasilopoulou, S. (2018a). Theory, concepts and research design in the study of Euroscepticism. In B. Leruth, N. Startin, \& S. Usherwood (Eds.), The Routledge handbook of Euroscepticism (pp. 22-35). London, U.K.: Routledge.

Vasilopoulou, S. (2018b). The party politics of Euroscepticism in times of crisis: The case of Greece. Politics, 38(3), 311-326. 